2 Hathaway WE, Mahasandana C, Makowski EL. Cord blood coagulation studies in infants of high-risk pregnant women. Am J Obstet Gynecol 1975;121:51-7.

3 Condie RG. Components of the haemostatic mechanism at birth in pre-eclampsia with particular reference to fetal growth retardation. Br J Obstet Gynaecol 1976;83: 943-7.

4 Cederholm-Williams SA, Spencer JAD, Wilkinson AR. Plasma levels of selected haemostatic factors in newborn babies. Thromb Res 1981; 23:555-8.

5 Ekelund H, Hedner U, Nilsson IM. Fibrinolysis in newborns. Acta Paediatr Scand 1970;59:33-43.
6 Biland L, Duckert F. Coagulation factors of the newborn and his mother. Thromb Diath Haemorrh 1973;29:644-51

7 Kries RV, Jurgens H, Voss HV, Gobel U. The clinical relevance of factor VIII:C and factor VIII:A determination in newborns. Eur J Pediatr 1981 ;137:189-94.

Correspondence to $\operatorname{Dr}$ A R Wilkinson, Neonatal Unit, Department of Paediatrics, John Radcliffe Maternity Hospital, Headington, Oxford OX3 9DU.

Received 27 May 1983

\title{
Expiration induced femoral flow in neonatal coarctation of aorta
}

\section{B MCNICHOLL AND J D KENNEDY}

\section{Departments of Paediatrics and Pathology, Regional Hospital and University College, Galway, Ireland}

SUMMARY In a 3 day old infant with coarctation of the aorta a loud Doppler signal synchronous with expiration was present for some hours in the femoral vessels, with only barely audible signals synchronous with cardiac systole. It is suggested that in the presence of severe aortic constriction and temporary ductal closure, blood was pumped through the infradiaphragmatic arteries by increased intrathoracic expiratory pressure.

We believe that the following phenomenon may not have been reported before.

\section{Case report}

A baby girl aged 72 hours was transferred from another hospital because of pallor and pyrexia. Her birth had been normal, at term, and she weighed $3.82 \mathrm{~kg}$. At $12.15 \mathrm{am}$ the infant was slightly cyanosed, there was forceful grunting expiration at a rate of $56 / \mathrm{min}$, her cardiac rate was $150 / \mathrm{min}$, and her liver edge was palpable $4 \mathrm{~cm}$ below the costal margin in the right nipple line. Praecordial and epigastric pulsation were prominent but femoral pulsation was not detected. The blood pressure in both arms was $150 \mathrm{~mm} \mathrm{Hg}$ systolic (Doppler ultrasound, $3.5 \mathrm{~cm}$ cuff). When the Doppler probe was placed sequentially over the femoral arteries a loud signal synchronous with expiration was heard over each artery and very faint signals synchronous with cardiac systole were audible on increasing the volume of the ultrasound. The expiration induced signal was heard at a lower intensity in the right popliteal fossa and was abolished by $20 \mathrm{~mm} \mathrm{Hg}$ pressure in a $5 \mathrm{~cm}$ cuff on the thigh.

Digoxin, frusemide, and oxygen were given and arrangements were made for transfer to hospital in Dublin later that morning. About 8 hours later blood pressure in the right arm was $120 \mathrm{~mm} \mathrm{Hg}$ and the expiration induced signal had been replaced in the groins by one synchronous with systole. The femoral systolic artery pressure was $70 \mathrm{~mm} \mathrm{Hg}$. As she was being transferred cardiac arrest occurred.

At necropsy the essential findings were a hypoplastic aortic arch with a tight infantile coarctation immediately distal to the left subclavian artery. There was a patent but narrow ductus. The other relevant findings were right ventricular dilation and hypertrophy, anatomically patent but functionally closed foramen ovale, and normal thoracoabdominal aorta. The aortic valve was tricuspid and no endocardial fibroelastosis was seen.

\section{Discussion}

During the initial observations blood flow in the femoral arteries coincided with expiration and virtually no flow synchronous with cardiac systole was detectable. We presume that at that time ductal closure occurred which added to the severe aortic constriction and severely restricted flow into the descending aorta. We suggest that the flow detected in the femoral arteries was induced by the pumping action of a high intrathoracic expiratory pressure on the descending aorta, sufficient to produce a pressure of at least $20 \mathrm{~mm} \mathrm{Hg}$. Since an expiratory intrathoracic pressure of $92 \mathrm{~cm} \mathrm{H}_{2} \mathrm{O}(67.6 \mathrm{mg} \mathrm{Hg})$ has been recorded in a neonate ${ }^{1}$ and pressure of about $240 \mathrm{~cm} \mathrm{H}_{2} \mathrm{O}(176.5 \mathrm{~mm} \mathrm{Hg})$ in an adult male undergoing physical stress, ${ }^{2}$ it seems reasonable that with retrograde flow largely prevented by aortic and ductal constriction, high intrathoracic pressure could pump blood in the descending aorta downwards. This would imply that sufficient blood was 
reaching the aorta through the coarctation, the ductus, and collateral vessels to be pumped caudally. When the final observations were made the more usual femoral flow synchronous with systole presumably resulted from intervening dilatation of the ductus. Expiration induced femoral flow may be useful as an indicator of ductal closure in coarctation.

We thank Professor P W Walton of this University for advice concerning Doppler mechanisms and Professors C A Smith, G S Dawes, and $\mathrm{K}$ W Cross for help in elucidating problems of intrathoracic pressure changes in neonates.
References

1 Milner AD, Saunders RA, Pressure and volume changes during the first breath of human neonates. Arch Dis Child 1977;52:918-24.

2 Altmann PL, Dittmer DS. Respiration and circulation. Federation of American Societies for experimental biology: Bethesda, 1971:86.

Correspondence to Professor B McNicholl, University College, Galway, Eire.

Received 19 May 1983

\title{
Serum thyroxine and thyroid stimulating hormone values in unreferred children with short stature
}

\author{
G V VIMPANI, A F VIMPANI, J W FARQUHAR, AND J SETH \\ The Department of Child Life and Health, University of Edinburgh and the Royal Infirmary, Edinburgh
}

SUMMARY Of 449 children aged 6-9 years with heights below the first centile in a total population of 48221 , only 1 had previously undiagnosed hypothyroidism. In a community with well developed health services hypothyroidism is unlikely to be the cause of short stature among primary school children.

Primary hypothyroidism has been described as the commonest endocrine cause of short stature. ${ }^{1}$ This was tested in a total population study designed to find the prevalence of growth hormone deficiency.

\section{Subjects and methods}

The screening of height in this group has been described. ${ }^{2} 3$ Many children were excluded because of previous negative studies (10), previous diagnosis of an organic cause (82), insufficient residual blood (6), and parental refusal (77). Two hundred and sixty seven children had thyroxine (T4) and 274 thyroid stimulating hormone (TSH) estimations. Serum T4 and TSH values were determined by radioimmunoassay with between assay coefficients of variation of 11.7 and 5.1 percent respectively. Bone age was determined by radiographic examination of the left wrist.

\section{Results}

Serum T4. The distribution of T4 concentrations is shown in Table 1. Values did not differ appreciably in boys and girls (mean (SD) $116.5(21.4) \mathrm{nmol} / \mathrm{l}$ $(9 \cdot 1(1 \cdot 7) \mu \mathrm{g} / \mathrm{dl})$ and $118 \cdot 3(17 \cdot 9) \mathrm{nmol} / \mathrm{l}(9 \cdot 2(1 \cdot 4)$ $\mu \mathrm{g} / \mathrm{dl})$ ). Those with values exceeding $161 \mathrm{nmol} / \mathrm{l} \mathrm{had}$ normal TSH values and were clinically euthyroid.
There was no correlation with sex, age, height, or bone age. Six children had values in the lower range for normal adults $(75-80 \mathrm{nmol} / \mathrm{l})$ and of these, 2 were being treated for coeliac disease. Another had a marginally raised TSH $(7.3 \mathrm{mU} / 1)$, the upper limit of normal being $5.7 \mathrm{mU} / \mathrm{l}$. He had been a 'light for dates' twin, of 42 weeks' gestation, and of below average intelligence. He was clinically euthyroid.

Serum TSH values. The distribution of TSH values shown in Table 2 approximates to that of a $\log$ normal curve.

One 7 year old girl had a value of $98.4 \mathrm{mU} / 1$. Her parents were small. One paternal relative had thyrotoxicosis and 2 others were type I diabetics. Her hair was dry and she was often sleepy but there were no other features and her IQ was 107 (Wechsler intelligence scale). Bone age was 3 years retarded

Table 1 Distribution of serum thyroxine (T4) values in 267 children aged 6-9 years

\begin{tabular}{lccc}
\hline Serum thyroxine (nmol/l) & Boys & Girls & Total \\
\hline$<70$ & - & - & - \\
$71-80$ & 5 & 1 & 6 \\
$81-90$ & 9 & 7 & 16 \\
$91-100$ & 22 & 8 & 30 \\
$101-110$ & 29 & 22 & 51 \\
$111-120$ & 28 & 24 & 52 \\
$121-130$ & 28 & 27 & 55 \\
$131-140$ & 12 & 14 & 26 \\
$141-150$ & 13 & 7 & 20 \\
$151-160$ & 2 & 3 & 5 \\
$>161^{*}$ & 5 & 1 & 6 \\
\hline Total & 153 & 114 & 267 \\
\hline
\end{tabular}

Conversion: SI to traditional units-thyroxine $1 \mathrm{nmol} / 1 \approx 0.08 \mu 1 / \mathrm{dl}$. *Five children had T4 values $>162 \mathrm{nmol} / \mathrm{l}$ and were clinically euthyroid. Their T4 and TSH values (TSH normal value $\approx 2.2 \mathrm{mU} / \mathrm{l}$ ), were; $170(3 \cdot 7), 172(2 \cdot 0), 175(4 \cdot 3), 190(5 \cdot 1)$, and $210(5 \cdot 4)$. 